Gerión. Revista de Historia Antigua

ISSN: 0213-0181

\title{
El desierto de Ildefonso de Toledo. Notas sobre la construcción de la autoridad episcopal en el reino visigodo
}

\author{
Dolores Castro ${ }^{1}$
}

Recibido: 3 de abril de 2018 / Aceptado: 24 de enero de 2019

Resumen. En este artículo se analizan los usos de la imagen del desierto en De itinere deserti de Ildefonso de Toledo, una obra breve, elaborada a mediados del siglo VII, en la que se destaca el ideal de austeridad y disciplina de los santos. A partir de la selección y combinación de elementos bíblicos y patrísticos, Ildefonso enfatiza la centralidad del desierto en una obra destinada a impartir instrucciones de salvación a todos los bautizados. En este marco, De itinere deserti invita a indagar los modos de construcción de la autoridad episcopal en el siglo VII en general y en el contexto toledano en particular.

Palabras clave: desierto; Ildefonso de Toledo; santos; autoridad.

\section{[en] The Desert of Ildefonsus of Toledo. Notes on the Construction of Episcopal Authority in the Visigothic Kingdom}

Abstract. This study focuses on the uses of the image of desert in De itinere deserti by Ildefonsus of Toledo, a brief work written in the mid-seventh century regarding the ideal of the saint's austerity and discipline. By carefully selecting and combining biblical and patristic elements, Ildefonsus underscores the prominent place of the desert in a work offering salvation guidelines for all the baptized. In this framework, De itinere deserti invites to explore the construction of episcopal authority in the seventh century and, more specifically, in the Toledan context.

Keywords: Desert; Ildefonsus of Toledo; Saints; Authority.

Sumario. 1. Introducción. 2. El desierto: entre el Antiguo y el Nuevo Testamento. 3. Itinerario de la vida presente. 4. La ciudad regia: ¿un desierto o una nueva Babilonia? 5. Consideraciones finales. 6. Referencias bibliográficas.

Cómo citar: Castro, D. (2019): El desierto de Ildefonso de Toledo. Notas sobre la construcción de la autoridad episcopal en el reino visigodo, en Gerión 37/1, 177-199.

1 Instituto Multidisciplinario de Historia y Ciencias Humanas (CONICET); Universidad Nacional de General Sarmiento, Argentina.

E-mail: dolorescastro@gmail.com 
"Los desiertos se llaman así (deserta) porque no se siembran (serere) y, en consecuencia, están abandonados (deserere). Son, por ejemplo, los lugares de las selvas y los montes que son lo contrario de tierras ubérrimas, como feraces son los campos cultivados". 2

\section{Introducción}

En esta definición de Isidoro de Sevilla, procedente del Libro XIV de las Etimologías, el término deserta hace referencia a los lugares yermos, deshabitados y abandonados. En la misma obra, además, el obispo hispalense anotaba también que a estos sitios solían retirarse en solitario los anacoretas y eremitas. ${ }^{3}$ En este último sentido, el desierto se consagraba como lugar contemplativo por excelencia, el de los llamados Padres del desierto quienes habiéndose refugiado en la soledad y el páramo definieron en los siglos III y IV una nueva forma de concebir la perfección espiritual. Sin embargo, el desierto no siempre evocó un lugar geográfico concreto. En cambio, se caracterizó por adoptar un conjunto amplio de significados que podían remitir tanto a lo peligroso y a lo desconocido como a diversos modos de representar la relación con la divinidad o el tránsito del hombre cristiano por la ciudad terrestre.

Es Ildefonso de Toledo quien, en la segunda mitad del siglo VII, retoma el tópico del desierto en un opúsculo conocido actualmente como De itinere deserti, elaborado durante su episcopado en la sede toledana entre los años 657 y $667 .{ }^{4} \mathrm{El}$ desierto desempeña en la obra un papel central, al erigirse como principal elemento definitorio de un mensaje destinado a orientar al hombre bautizado a lo largo de un camino que debía conducir a la vida futura. Desde luego, la elección del desierto no era arbitraria en Ildefonso, un monje-obispo formado en el monasterio de Agali, ubicado en las cercanías de la capital. Tampoco puede desvincularse del desarrollo general del monacato en el reino visigodo durante los siglos VI y VII, un fenómeno de carácter heterogéneo y multiforme, o de la creciente importancia que los valores ascéticos habían adquirido en la literatura hagiográfica en general. ${ }^{5}$

Apelar al desierto implicaba, por lo tanto, un espectro semántico variado en el que se conjugaron principalmente las tradiciones bíblica y patrística. Desde el Éxodo y el Evangelio hasta los Padres del desierto en Egipto y la difusión del monasticismo en Occidente, el tópico del desierto transitó por diversos derroteros que, a su vez, destacaron aspectos centrales de la vida cristiana.

Con el objetivo de analizar los usos de la imagen del desierto en la obra del toledano y su rol en la construcción de la autoridad episcopal en el siglo VII, este estudio entre-

2 Isid. Etym. 14.8.31: Deserta vocata quia non seruntur et ideo quasi deseruntur; ut sunt loca silvarum et montium, contraria uberrimarum, quae sunt uberrimae glebae. La traducción es de Oroz Reta - Marcos Casquero 2004.

3 Isid. Etym. 7.13.3-4: Anachoritae sunt qui post coenobialem vitam deserta petunt et soli habitant per deserta; et ab eo, quod procul ab hominibus recesserunt, tali nomine nuncupantur; sed anachoritae Heliam et Iohannem, coenobitae Apostolos imitantur. 4. Eremitae hi sunt, qui et anachoritae, ab hominum conspectu remoti, eremum et desertas solitudines appetentes. Nam eremum dicitur quasi remotum.

4 Si bien no es posible brindar una fecha exacta de elaboración de este tratado, los especialistas coinciden en situarla en el periodo en que Ildefonso ejerció las funciones episcopales en Toledo (657-667). Así lo afirman, entre otros, Braegelmann 1942; Madoz 1952; Robles 1970 y Yarza Urquiola 2007.

5 Sobre estos temas, véase: Díaz 1986 y 1999; Fernández Ardanaz 1999; De Vogüé 2007; Velázquez 2007; Castellanos 2011; Martín Viso 2011 y 2012. 
laza dos interrogantes: se propone explorar, en primer lugar, las tradiciones en las que se basa el De itinere deserti, con especial énfasis en la tradición bíblica, principalmente veterotestamentaria. En segundo lugar, busca indagar el vínculo establecido entre el ideal de comportamiento cristalizado en el desierto y el contexto específico en el que se inscribe la producción teológico-pastoral de Ildefonso. Desde la urbs regia, y de la mano de la principal autoridad eclesiástica del reino, De itinere deserti delineaba un modelo de conducta que instalaba como pilar de salvación el más severo ascetismo, definiendo criterios de santidad demasiado rigurosos, apenas alcanzables para un sector harto reducido del clero. La apuesta del toledano, por lo tanto, restablecía un modo de concebir la vida en la tierra asociado al desierto, animando a sus lectores a imitar las prácticas ascéticas atribuidas a los santos, índices de prosperidad por excelencia.

¿Qué implicaciones comprendía un mensaje que, procedente del centro político y religioso más importante del territorio peninsular, reivindicaba la mesura, el rigor y la disciplina? ¿Suponía, pues, una advertencia o admonición destinada a las principales fuerzas políticas del reino? ¿Constituía una herramienta de disciplina en un periodo en el cual imperó en Toledo un prolongado paréntesis conciliar? Por último, ¿qué significado tenía para la ciudad un mensaje que hacía del desierto el estandarte de santidad por excelencia?

Antes de comenzar a desandar este conjunto de interrogantes, recordemos brevemente que Toledo, convertida en urbs regia desde mediados del siglo VI, era uno de los núcleos urbanos más relevantes de la Península: desde la fijación de la residencia del rey y de la corte hasta las sucesivas políticas edilicias y cultuales concentradas en la ciudad y sus alrededores, diversos factores intervinieron en el proceso de su encumbramiento. Desde luego, la vigorización de Toledo no había sido solo una iniciativa monárquica. La actividad del obispo contribuyó igualmente a su exaltación y promoción: la tarea pastoral, la producción de obras doctrinales y teológicas, la enseñanza, la creación y el control de los canales apropiados para comunicar los misterios divinos, la homogeneización de las prácticas litúrgicas, entre otras prerrogativas que se extendían también al gobierno y planeamiento de la ciudad, se conjugaron para hacer de Toledo en general, y de su iglesia en particular, el baluarte de la ortodoxia más importante del paisaje peninsular. Dentro del mapa eclesiástico jerárquico de la Iberia tardoantigua, otros centros episcopales habían gozado también de una destacada posición: Hispalis en la Bética, Zaragoza o Mérida, entre otros ejemplos, constituyeron núcleos de gran envergadura que intervinieron activamente, con mayor o menor intensidad, en la organización religiosa, social, económica y política del reino visigodo de los siglos VI y VII.

Es en este contexto en el que Ildefonso retoma, una vez más, la tradición del desierto y reactiva un mensaje centrado en su austeridad, irradiando rigurosidad y disciplina a la ecclesia en su totalidad, mas especialmente apelando con su mensaje a los rectores del reino, a los responsables de la instrucción y conducción de la feligresía. En este sentido, el obispo dejaba entrever que, lejos del retiro en solitario y el aislamiento geográfico, el desierto tenía la vía expedita hacia la ciudad: Toledo y sus representantes podían alcanzar un índice de santidad aun mayor si absorbían las indicaciones de rigurosa moral emanadas del De itinere deserti. ${ }^{6}$

6 Utilizamos en este artículo la edición más reciente de la obra toledana, elaborada por Yarza Urquiola (2007). Las traducciones al español corresponden al trabajo de Campos 1971. Asimismo, respetamos la grafía de las ediciones consultadas. 


\section{El desierto: entre el Antiguo y el Nuevo Testamento}

En el Antiguo Testamento el desierto es el gran escenario del Éxodo, de la marcha del pueblo de Israel después de su liberación de Egipto hasta llegar conducido por Moisés a la tierra prometida. De acuerdo con Guillaumont, la concepción veterotestamentaria del desierto se alimenta efectivamente de dos sustratos principales: uno "místico o idealista" que evoca el pasado de Israel y los tiempos mesiánicos (la alianza entre Dios y el pueblo elegido) y otro "realista o negativo", común en el Oriente Próximo en general, que concebía al desierto como la morada por excelencia de las bestias y los demonios, en oposición a la tierra cultivada y habitada. ${ }^{7}$ Dentro de la primera acepción, como bien señaló Rapp, el Antiguo Testamento, y el Libro del Éxodo en particular, hace del desierto un locus de intervención divina, en donde se produce el contacto entre el hombre y la divinidad. En palabras de la autora: "the desert functions mostly as a place of encounter with God, who made his presence known through revelation, chastisement, nourishment, and protection". ${ }^{8}$ Los ejemplos en este sentido son abundantes: diversos encuentros entre Dios y Moisés acontecen en el desierto, siendo el más conocido la entrega de las tablas de la Ley en el monte Sinaí. ${ }^{9}$

En De itinere deserti Ildefonso adopta una lectura esencialmente espiritual del Antiguo Testamento, heredada a su vez de los antiguos Padres, a partir de la cual era retomado el paralelo entre la marcha del pueblo hebreo en el desierto y el trayecto espiritual del hombre cristiano. Esta interpretación del episodio veterotestamentario, ${ }^{10}$ cultivada vigorosamente por el toledano, prefiguraba en el éxodo judío el tránsito del hombre en este mundo. El desierto, por lo tanto, era un símbolo de la vida presente, un éxodo que el cristiano debía atravesar para alcanzar la vida futura, la Jerusalén celeste o, en otras palabras, para dirigirse ad mansionem aeternae vitae. De esta forma, el relato del Antiguo Testamento enseñaba su verdadero sentido en un nuevo contexto y dirigido también a una nueva audiencia. El mensaje, revestido de un tono exhortativo, anunciaba: "Es hora ya de considerar este camino de prosperidad que siguen los santos en el desierto, y con ellos, a su imitación, marchemos. Se entiende de los que después de pasar el mar Rojo, caminando por el desierto, confiaban llegar, según la veraz promesa de Dios, a la tierra de las promesas". ${ }^{11}$

Ahora bien, esta clave interpretativa de larga tradición atravesaba la obra del toledano de principio a fin. En De itinere deserti tomaba forma una exégesis figurativa que a partir de cadenas alegóricas y símbolos bíblicos se proponía exteriorizar el verdadero sentido de la revelación, aquel que observaba en el Nuevo Testamento el cumplimiento del Antiguo. Este procedimiento exegético, tal como advertía el toledano, se articulaba en torno de la relación entre la letra y el espíritu. En este

\footnotetext{
Guillaumont 1975, 4.

Rapp 2005, 107.

Ex 19.

10 Ildef. De itin. des. 12: Quam tamen legem spiritaliter intelligendo non inmoramur in amaritudine eius, sed cito properamus ad doctrinae aquas et uictoriae palmas, ubi per apostolos ubertate doctrinarum caelestium satiamur et spiritalis gloriae triumphis adtollimur.

$11 \quad$ Ildef. De itin. des. 15: Contemplemur iam hoc prosperabile iter, quod a sanctis agitur in deserto, et cum illis pari eorum imitatione ducamur. De his dicitur, qui post transitum maris Rubri per deserta pergentes secundum ueram promissionem Dei se uenire confidebant ad repromissionis terram.
} 
sentido, una imagen recurrente en la obra refería a las aguas amargas de Mara, ${ }^{12}$ utilizada para significar tanto la letra o sentido literal de las Escrituras como la relación hermenéutica entre ambos testamentos. En esta línea, afirmaba el obispo que del mismo modo en que tras atravesar el mar Rojo se había llegado a las aguas de Mara, después del bautismo se conoció la ley, pues el conocimiento histórico era anterior al entendimiento. ${ }^{13}$ Sin embargo, conocer el precepto, el amargor de su superficies, no conducía de forma inmediata a la perfección, sino que únicamente "(...) recibida la fe de la inteligencia espiritual e interpuesto el leño de la cruz de la pasión, se convierte en la dulzura de la fe; y todo lo que por su medio fue amargo, entendiéndolo piadosamente, se endulza". ${ }^{14}$ Ildefonso presentaba el paso de lo amargo a lo dulce, de la letra al espíritu, aludiendo también al simbolismo de la madera (vara de Moisés) como figura de la Cruz. ${ }^{15}$ La misma idea era desarrollada en capítulos posteriores. Por ejemplo, en De itin. des. 11: “(...) por el conocimiento de la ley, gustamos el amargor de la letra que mata. De esta ley, Dios es el único autor, lo mismo que de los evangelios" 16 y en De itin. des. 12: “(...) entendiendo, sin embargo, espiritualmente esta ley, no se detiene en su amargor, sino en seguida nos apresuramos a las aguas de la doctrina y a las palmas de victoria". ${ }^{17}$ Nuevamente en palabras de Ildefonso, el Evangelio había iluminado al hombre inmerso en "las tinieblas y en la sombra de la muerte". ${ }^{18}$ Por lo tanto, el contenido literal era aquel considerado como primero, esto es, exterior (superficies) o inmediato, es decir, carente de profundidad. Desde esta perspectiva, pues, la relación letra/espíritu codificaba el nexo entre el Antiguo y el Nuevo Testamento, y la transformación de las aguas de Mara de amargas a dulces, el paso de uno a otro. En otras palabras, sin el Evangelio, sin el espíritu, la letra amarga y carnal mata. Recordemos que este tópico había sido trabajado intensamente por la tradición, en particular por Jerónimo y Agustín, y su origen se remontaba incluso al corpus paulino, más específicamente a la Segunda carta a los Corintios. ${ }^{19}$

Finalmente, el sentido o interpretación literal de las Escrituras había sido desde antiguo asociado a los judíos. ${ }^{20}$ En esta línea interpretaba Ildefonso el significado de la higuera, fuente constante de alimento y dueña de un fruto dulce y delicioso, que al desechar los primeros frutos inmaduros, símbolo de la ley de los judíos, conducía a

12 Ex 15,23.

13 Ildef. De itin. des. 8.

14 Ildef. De itin. des. 8: Sed, accepta fide intelligentiae spiritalis et ligno Christi immixto, uertitur in dulcedinem fidei, et quicquid, illa saeuiente, amarum fuit, pie intelligendo dulcescit.

15 Ildefonso apela a este simbolismo también en De cognitione baptismi, en el capítulo 101: “Allí el vasto mar es dividido por la vara, aquí se abre el acceso a la fuente con el signo de la Cruz".

16 Ildef. De itin. des. 11: (...) sic per cognitionem legis amaritudinem occidentis litterae adtentamus. Cuius legis idem qui et euangeliorum unus auctor est Deus.

17 Ildef. De itin. des. 12: Quam tamen legem spiritaliter intelligendo non inmoramur in amaritudine eius, sed cito properamus ad doctrinae aquas et uictoriae palmas (...).

18 Ildef. De itin. des. 13.

192 Cor 3,6. Según Kannengiesser 2004, 184, al proclamar en su segunda epístola a la comunidad de Corinto que la letra mata pero el Espírtu da vida, Pablo "referred to an age-old conviction inside the interpretive school of Pharisaism, according to which the written Torah needed an oral or spiritual complement; but he also made the unheard of claim that only the "Spirit gives life", and not the Law as such".

20 Desde los primeros siglos del cristianismo los judíos fueron asociados a la idea de 'ceguera' o 'sordera'. Fredriksen - Irshai 2006, 982: “The more fundamental explanation for the Jew’s deafness or blindness to Christian claims, however, says Justin, is their enduring national character. As the Scriptures themselves display and as the prophets especially proclaimed, Jews are intransigently hard-hearted, carnal, stubborn, sinful, and idolatrous". 
los fieles a la dulzura del Evangelio. ${ }^{21}$ En efecto, de acuerdo con la tradición, era el pueblo judío el que al negar a Cristo había negado también la inteligencia espiritual de las Escrituras y se limitaba únicamente a un entendimiento carnal o literal de los textos bíblicos. Como vimos, la relación (de raíz bíblica) entre una letra que asesina y un espíritu que da vida impregnó profundamente la obra toledana, preocupada por impartir un único modo de interpretar las Escrituras. La historia de Israel, por tanto, debía necesariamente estar dirigida a Cristo, en quien encontraba su pleno sentido y único fin.

Ahora bien, en este punto es necesario recordar que De itinere deserti había sido concebido por Ildefonso como complemento y continuación de De cognitione baptismi, una obra, un poco más extensa, donde el toledano repasaba puntos doctrinales esenciales del cristianismo, con especial énfasis en el sacramento del bautismo. Allí también las enseñanzas del Antiguo Testamento estaban presentes, principalmente en los capítulos 98 y 99 a través de los cuales Ildefonso enseñaba el sentido figurativo del Éxodo, en particular, el del cruce del mar Rojo durante la liberación del pueblo de Israel. Tomando, en esta ocasión, la exégesis paulina (principalmente 1 Cor 10,1$)^{22}$ como principal clave de lectura, Ildefonso apuntalaba el nexo entre éxodo y bautismo: del mismo modo en que el pueblo de Israel guiado por Moisés atravesaba las aguas del mar Rojo liberándose de la dominación egipcia, el hombre era conducido a la fuente bautismal en la que era liberado gracias a Cristo. Del mismo modo en que Cristo vencía al pecado y al demonio, Moisés había vencido al faraón y a su ejército. El agua, por lo tanto, constituía un signo que permitía la redención del elemento humano tanto en el éxodo como en el bautismo, al representar la destrucción (exitium) para unos y la ayuda (subsidium) para otros. ${ }^{23}$ Como el pueblo de Israel antes del paso por las aguas, el hombre permanecía antes del bautismo en situación de servidumbre: prisionero de los pecados, de los placeres mundanos y de las tentaciones demoníacas. Desde esta perspectiva, por lo tanto, el sacramento bautismal era entendido como liberación y Cristo como salvador, como un nuevo Moisés. ${ }^{24}$ Este paralelismo era desarrollado de forma más extensa en el capítulo 101: "Moisés es el jefe de la salvación de Israel. Jesús fue constituido jefe de la redención del hombre. Aquél dejó Egipto, éste el mundo. A aquél le siguen los egipcios, a éste le sigue la multitud del delito". ${ }^{25}$

Sin embargo, la iniciación en la vida cristiana a través del bautismo no implicaba una vía directa e inmediata hacia el destino salvífico, sino el necesario inicio de un largo camino, de un éxodo, que exigía del hombre bautizado la adopción de normas de conducta de riguroso ascetismo. Si la meta consistía, por lo tanto, en alcanzar la vida futura, el bautismo constituía un punto decisivo, pues representaba la puerta de entrada a la ecclesia, un primer requisito a partir del cual el hombre se inscribía dentro de la comunidad y se veía a sí mismo formando parte de un universo creado y deseado por la divinidad. Pero, como bien ilustraba Ildefonso en su De itinere deser-

$21 \quad$ Ildef. De itin. des. 33.

22 Ildef. De cogn. 102: Figuram et typum baptismi huius bene Paulus commendans dicit: Nolo uos ignorare, fratres, quia omnes patres nostri sub nube fuerunt, et omnes per mare transierunt. Vtquid per mare transierunt? Quasi quaereres ab illo, secutus ait: Omnes per Moysen baptizati sunt in nube et in mari.

23 Ildef. De cogn. 101.

24 Cf. Ildef. De cogn. 97.

25 Ildef. De cogn. 101: Est saluando Israheli dux Moyses, factus est redimendo homini dux Ihesus. Ille relinquit Aegyptum, iste mundum. Illum insequuntur Aegyptii, hunc insequitur multitudo delicti. 
$t i$, para estar en condiciones de alcanzar esa vida futura era indispensable llevar adelante una vida conforme a las normas cristianas, regida por la austeridad y la práctica ascética. La instrucción era, por lo tanto, indispensable. En este sentido, la obra del toledano aportaba valiosos recursos, espirituales y morales, para que los bautizados pudieran afrontar las vicisitudes del camino. Nuevamente la lectura figurativa de Ildefonso ubicaba al obispo en el mismo plano que Moisés. ${ }^{26}$ Mientras que este último abrió con su vara las aguas del mar Rojo para la liberación, el magistrado eclesiástico tocaba las aguas de la fuente para habilitar el acceso al remedio de salvación ${ }^{27}$ y la vida eterna. A partir de este desarrollo, el bautismo, uno de los sacramentos principales de la iglesia tardoantigua y altomedieval, se instalaba como mecanismo de absoluta necesidad para cumplir el propósito salvífico, excluyendo y volviendo obsoleta cualquier interpretación alternativa del episodio veterotestamentario. Desde esta perspectiva, entonces, no existía posibilidad de salvación al margen de una iglesia cristiana que movilizaba una única interpretación de un único texto sagrado.

Por último, el toledano también se alimenta de la tradición profética, especialmente de Isaías, para exhibir al desierto no ya como escenario deshabitado, sino provisto de la más variada flora y fauna, colocadas allí por obra exclusiva de la divinidad. De acuerdo con Ildefonso, en la marcha espiritual por el desierto el hombre recibía los dones del Espíritu Santo: ${ }^{28}$ árboles, flores, plantas, aves y otros animales que ofrecían ayuda y protección, tal como había sido anunciado por el profeta con estas palabras: "Pondré en el desierto cedros, acacias, arrayanes y olivares. Pondré en la estepa el enebro, el olmo y el ciprés....". ${ }^{29}$ Pero la lectura de Ildefonso era, una vez más, una lectura en clave espiritual, y adjudicaba a los dones carismáticos un rol principal en la construcción del vínculo con la divinidad. Dice el obispo: "Hay también dones de carismas prevenientes, con los que, junto con éstos, nos fortalece el Espíritu Santo en esta vida viajera, que Cristo nos otorgó con la prenda de su piedad para que no queden desfallecidos en el camino a quienes, debiendo ser fortalecidos, conducirá a la patria". ${ }^{30}$

Ildefonso emprendía, de este modo, una descripción espiritual de los paisajes y los seres naturales que los habitaban: señalaba la hermosura de montes y bosques (que ofrecían sus frutos y la dádiva de su verdor a aquellos destinados al descanso eterno), aludía a las aves inocentes, que alegraban al hombre y lo orientaban hacia Dios con sus dulces melodías o lo deleitaban con la hermosura de sus gracias, sirviendo de solaz al viajero y aliviando las adversidades del camino con su protectora compañía. ${ }^{31}$ En la misma línea exegética, Ildefonso explicaba el sentido alegórico de una serie de seres vegetales, animales y minerales de aparición frecuente en las Es-

\footnotetext{
26 Acerca de Moisés como modelo de liderazgo episcopal, véase Sterk 1998 y Rapp 2005, entre otros.

27 Cf. Ildef. De cogn. 92.

28 Ildef. De itin. des. 34: In hoc deserto et uerbis et mysteriis propheticis commendato inueniuntur stagna et riui aquarum.

29 Is $41,19$.

$30 \quad$ Ildef. De itin. des. 24: Sunt quoque et praecedentia charismatum dona, quibus pariter cum his Sanctus Spiritus in hac peregrinatione nos reficit, quem dedit nobis Christus in pignere pietatis, ut deficientes non habeat in uia quos reficiendos deducat in patriam.

31 Ildef. De itin. des. 53: Quin etiam distincta pulchritudine montium ac nemorum, quae et uiriditatis et fructuum consolationem peruenturis ad aeternam requiem exhibent in ostensione uirtutum, adsunt quoque et bonarum auium considerationes praespicuae, quae uiatorem Dei uel dulci melos refouent, uel gratiae aspectu iucundant, manentes in solatium uiatori angoremque itineris protectionis comitatu solantes.
} 
crituras como el mirto, ${ }^{32}$ la espina, ${ }^{33}$ el olivo, ${ }^{34}$ el cedro, ${ }^{35}$ el abeto, ${ }^{36}$ la vid, ${ }^{37}$ entre otros. También el pino, la caña, el boj, el lirio y el hisopo se sumaban al listado de plantas, árboles y frutos a través de los cuales se significaban las virtudes espirituales. Inspirado a su vez en la tradición, especialmente en Gregorio Magno y Agustín de Hipona, ${ }^{38}$ el toledano ilustraba lo antedicho con algunos ejemplos: el mirto era representación de la templanza, el junco de la obediencia, el olivo de la misericordia y el abeto de la contemplación de los bienes celestiales. Desde la perspectiva de este mundo simbólico, repleto de imágenes de Cristo, verdadero guía del hombre en el desierto, se advertía la potencia divina capaz de intervenir y de manifestarse a través de los dones carismáticos en la vida del hombre, ${ }^{39}$ a los cuales Ildefonso otorgaba pleno protagonismo a la hora de definir una autoridad que, como veremos más adelante, poco dependía de los logros mundanos o bienes terrenales.

La función del desierto como locus de intervención divina se extendía también a la tradición neotestamentaria, tal como se advierte en los sucesivos encuentros con la divinidad que ocurren en Judea. Sin embargo, aparecen allí también las fuerzas del mal, del demonio y sus secuaces siempre preparados para acechar al hombre e inducir su caída en el vicio y el pecado. El desierto representaba, desde esta perspectiva, un lugar de combate contra las tentaciones, tópico que el toledano explotará al máximo en la obra, pues, tal como enseñaba el Evangelio, el mismísimo Jesús había padecido en el desierto las tentaciones del diablo. ${ }^{40}$ Por otro lado, como ya ha señalado Rapp, el desierto se afirmaba también como lugar físico, alejado de la ciudad y sus disturbios, donde Jesús se había retirado en solitario ${ }^{41}$ o donde había predicado y bautizado Juan el Bautista.

\section{Itinerario de la vida presente}

En De itinere deserti, el desierto no hace referencia a un sitio concreto ni anclado en un territorio específico. Alude, como mencionamos, a un periodo intermedio entre el

32 Ildef. De itin. des. 37: Haec dum afflictis proximis compassione miserationis uel opem defert, uel consolationis eloquium impendit, ad spem salutis reparat quod pressuris inlisum dissolute atteri potuerat.

33 Ildef. De itin. des. 36: Spina doctrinae spiritalis, quae dum de peccatis ac uirtutibus disputat atque modo aeterna supplicia minatur, modo caeleste gaudium promittit, ita cor audientium pungit, ut dolore compunctionis perforatam mentem per oculos quasi quendam animae sanguinem lacrimas elicere cogat.

34 Ildef. De itin. des. 38: Oliua miserationis (...) cuius liquor ante aspectum Dei acceptabiliter satis fructu miserationis elucet.

35 Ildef. De itin. des. 35: Cedrus illa magni odoris, quae in sanctis uirtutes, et signa in operatione sua exhibens cum Paulo dicit: Christi bonus odor sumus Deo, tanto ad aeternitatis memoriam laudabilior, quanto et a putredine corruptionis gratior inuenitur et purior.

$36 \quad$ Ildef. De itin. des. 39: Abies contemplationis, quae intra sanctam Ecclesiam in terrenis corporibus posita iam caelestia contemplatur et, licet sit ortus eius ex terra, iam tamen contemplando uerticem mentis tollit in aethera.

37 Ildef. De itin. des. 31: (...) cuius uuae sanguis pretium mundi est, redemptio fidelium, abolitio delicti et praemium regni.

38 Cf. Yarza Urquiola, 2007.

39 Ildef. De itin. des. 18: Sic tota heremus uitae praesentis mundi destituta solatiis, spe futurae consolationis amabitur, quoniam ad patriam beatorum non melius, non celerius itur quam per angustias passionum, dicente Paulo: non sunt condignae passiones huius temporis ad futuram gloriam, quae reuelabitur in nobis. La acción del Espíritu Santo se advierte también en otras secciones del tratado. Por ejemplo, en De itin. des. 19: (...) uideamus delicias, quas illis in ea dux eorum per conlatum Sancti Spiritus pignus in solatium administrat (...).

40 Nos indica Rapp en Mt 4,1-11; Mc 1,12-13; Lc 4,1-13 (2005, 109, n. 26).

${ }^{41}$ Rapp 2005, 109: "The desert in the New Testament was also a concrete landscape, at a distance from the towns, where solitude could be found. Jesus often retreated to the desert to pray on his own. He also went there to escape the crowds - usually without success, as the people followed him anyway. At a great distance from sources of food, Jesus provided for his followers through the multiplication of loaves and fishes". 
bautismo o cruce de las aguas del mar Rojo y la entrada en la vida futura o tierra prometida. Simboliza, por lo tanto, el itinerario de la vida presente, donde el hombre cristiano, también llamado caminante o viajero, debía librar una "lucha" contra las tentaciones y los vicios; donde únicamente los soldados justos que lograran refugiarse en la contemplación y la humildad alcanzarían la salvación eterna, al rechazar al enemigo y sobrellevar la adversidad. Se distingue en este sentido el capítulo 15, donde Ildefonso hace predominar un vocabulario de fuerte connotación bélica, inspirado en las Escrituras, que describía el camino de prosperidad de los justos. Entre los términos más utilizados por el toledano destacan: "estuvieron firmes contra los enemigos" (steterunt contra hostes), "en la lucha de la guerra espiritual" (in acie spiritalis belli), "se defendieron de los enemigos" (de inimicis se indicaverunt), "la salvación de los soldados justos" (salus sanctorum militum), "ante el ataque de los poderes del aire" (ante impetum aeriae potestatis) y "armas de la justicia" (arma iustitiae), entre otras expresiones procedentes mayoritariamente del Libro de la Sabiduría. ${ }^{42}$ Es significativo el uso de Sab 11,2-43 para describir al desierto como un "lugar" deshabitado donde transcurre la incesante lucha contra los enemigos y las tentaciones. En este sentido, la idea de un combate espiritual situado en el desierto pone de manifiesto "un archétype éminemment évangélique, celui de la tentation de Jésus (Mt 4,1-11; Mc 1,12-13; Lc 4,1-13) et de sa lutte contre le mal, la maladie et la mort" ${ }^{44}$ Como mencionamos, desde esta clave de lectura el desierto era entendido como viaje o peregrinación, a lo largo del cual el hombre se encontraba necesariamente frente a obstáculos y dificultades diversas. Sin embargo, inspirado en el mensaje bíblico, Ildefonso dejaba entrever que aquel que lograra sortear con éxito los inconvenientes, sería conducido finalmente a la salvación. El toledano advertía que este camino no era de fácil acceso o, en otras palabras, que la salvación no solo no era automática ni inmediata, sino que podía ser alcanzada con sufrimiento y turbación.

A partir del desierto Ildefonso proponía llevar a la práctica un ideal de comportamiento basado en un riguroso ascetismo y en la renuncia radical a los placeres terrenales y bienes materiales. Para el obispo, como vimos, este desierto no se identificaba con un lugar geográfico como lo había sido, por ejemplo, para los primeros Padres del desierto. Recordemos que en el transcurso del siglo IV -y al calor de la emergencia del movimiento monástico- en Egipto el desierto se convirtió (inspiración bíblica mediante) en el lugar de retiro por excelencia, donde los monjes forjaron una nueva experiencia espiritual. ${ }^{45}$ Es preciso anotar, sin embargo, que esta construcción idea-

$42 \quad$ Ildef. De itin. des. 15.

43 "Atravesaron un desierto deshabitado y fijaron sus tiendas en parajes inaccesibles; hicieron frente a sus enemigos y rechazaron a sus adversarios. Tuvieron sed y te invocaron: de una roca abrupta se les dio agua, de una piedra dura, remedio para su sed".

44 Uytfanghe 1985, 583.

45 Acerca de la concepción del desierto característica del movimiento monástico de Egipto, véase Guillaumont 1975. Este último, además, destaca el rol de Filón de Alejandría en la elaboración y posterior difusión del tópico: "Ce thème du désert considéré comme étant par excellence l'endroit où l'homme jouit du calme (...) se retrouve, après Philon, et sous son influence, dans toute une lignée d'auteurs chrétiens, quand ils parlent notamment de la solitude de Jean-Baptiste, ce prototype des anachorètes" (Guillaumont 1975, 8). También, Rapp 2005, 119: "The association of desert and mental rest, and the idea that the "desert" state of mind could be attained regardless of location, appeared in the literature of the Judeo-Christian tradition long before the first hermits began to populate the desert of Egypt. The first to mention it was Philo of Alexandria in the first half of the first century. Philo saw the desert not only as a desirable place far removed from the moral corruption of the town, but also as a location of ideal climatic conditions where the air was light and pure and which was therefore more conducive to askēsis". La bibliografía en torno del desierto es amplia. Remito al lector tan solo a algunas 
lizada del desierto, cubierta de cierto halo de pureza y tranquilidad, debe mucho al contexto helenístico del siglo I a.C., especialmente a la pluma de Filón de Alejandría. ${ }^{46}$ Según Guillaumont, en cambio, el desierto en el medio monástico de Egipto desconocía rasgos idílicos y era comúnmente concebido como el hábitat de demonios y de fuerzas hostiles, tal como se observa, por ejemplo, en la Vita Antonii de Atanasio de Alejandría, elaborada alrededor del año 365.

Estamos, por lo tanto, ante un tópico ambivalente. Incluso dentro del escenario monástico el desierto dejó de remitir a un sitio geográfico concreto y pasó a significar un 'estado interno' que podía ser alcanzado sin importar la localización específica. ${ }^{47} \mathrm{La}$ idea del desierto como el retiro espiritual por excelencia del movimiento monástico ganó fuerza en Occidente a partir de la circulación de escritos especialmente hagiográficos. La impronta de Juan Casiano fue, en este sentido, de particular importancia: sus principales obras, Institutiones y Collationes, cumplieron un significativo papel en el proceso de apropiación del desierto egipcio y de la conformación (y continuación) de una tradición en Occidente a lo largo de los siglos V y VI.

Hemos visto, pues, que al evocar el desierto y aconsejar el cumplimiento de una vida de acuerdo al mandato de los santos, Ildefonso se inspiraba tanto en la autoridad bíblicopatrística como ascética. El obispo aludía al desierto a partir de aquellos pasajes de las Escrituras que lo asociaban a la carencia, a lo deshabitado, vacío o solitario, ${ }^{48}$ tomando, por ejemplo, los ya mencionados pasajes del Libro de la Sabiduría.$^{49}$ En el desierto, dice el primado toledano, no existían "moradas del placer", "mansiones de corrupción", "felicidad terrena" o "deleites que sirvan de obstáculo a los caminantes que se dirigen a la tierra de los que viven". ${ }^{50}$ Tampoco, continuaba el obispo, existían allí "oídos halagados por los susurros letales de inmundas aves" ni "olfato infectado de aromas de muelle placer" ni "gusto corrompido por la acidez de la putrefacción antigua si brotare de la garganta endulzada por la gracia", tampoco el tacto "palpará la impureza de obras sórdidas". En esta sucesión de atributos se advierte la desconfianza hacia los sentidos en tanto eran considerados la puerta de entrada de los vicios y las tentaciones que acechaban permanentemente al hombre. El ideal de comportamiento que emanaba de la obra de Ildefonso planteaba, pues, un estricto control sobre el cuerpo y una moderación de las prácticas corporales con el fin de aplacar los placeres y las tentaciones que podían ingresar en el hombre a través del registro sensorial. En efecto, se advertía un fuerte interés eclesiástico en regular las conductas, enfatizando el modelo ascético que proponía la renuncia a los placeres carnales con el fin de obtener a través de la moderación del deseo corporal un acercamiento más profundo con la divinidad.

El desierto, por el contrario, era propio de la vida santa, ${ }^{51}$ donde, al tener como única guía a Cristo, los vicios de la carne debían ser rechazados. Era también "salu-

contribuciones fundamentales: Burton-Christie 1993; Goehring 1999; Dunn 2000; Leyser 2000; Sterk 2004; Dijkstra - van Dijk 2006.

46 Imagen profundizada posteriormente por Clemente de Alejandría y Orígenes (Cf. Rapp 2005).

47 Cf. Rapp 2005, 120.

48 Por ejemplo, en De itin. des. 15: Ingrediamur ergo et nos cum his iustis, de quibus dicitur: Iter fecerunt per deserta, quae non habitabantur.

49 Cf. Sab 11,2.

$50 \quad$ Ildef. De itin. des. 15: (...) illa certe, quae habitationes non habeant uoluptatum, ubi non sint mansiones corruptionum, ubi non terrena felicitas ad interitum mulcens, ubi nullae oblectationes, quae ad terram uiuentium properantes praepediant uiatores (...).

$51 \quad$ Ildef. De itin. des. 16: Ita denique adgredimur desertum sanctae uitae, in quo, desiccatis omnium carnalium uoluptatum humoribus, nihil inueniemus quod sit per contrarium pulchrum oculis aspectuque delectabile, in 
dable" e "ilustrado con la luz del sol de justicia", o sea Cristo, pues iluminaba a los viajeros que emprendían el camino a la morada eterna.

El desierto representaba la austeridad de la vida presente ${ }^{52}$ y para atravesarlo, indicaba el obispo, no hacían falta las piernas o los pies del cuerpo, sino únicamente el corazón. ${ }^{53}$ En este sentido, a partir de una sucesión extensa de pasajes bíblicos ${ }^{54}$ Ildefonso indicaba que el alma del hombre se alimentaba de "manjares espirituales", una vez liberada de los "nauseabundos humores" que invadían el espíritu. Las imágenes alimenticias que utilizaba Ildefonso, recurrentes en contextos monásticos y especialmente presentes en Agustín, ${ }^{55}$ representaban al hombre con "apetito de la salud", dispuesto a alimentarse de un "opulento banquete de virtudes". ${ }^{56}$

Del mismo modo, en otro capítulo, Ildefonso enumeraba las "enfermedades espirituales" que derivaban de la carne por medio de pasajes bíblicos procedentes de $L a$ carta a los Gálatas ${ }^{57}$ finalizando con las siguientes palabras: "los que practican tales excesos no heredarán el reino de los cielos" ${ }^{58}$ Se trataba, en resumen, de una lucha en el interior del hombre donde la única respuesta verdadera descansaba en adoptar una conducta signada por la austeridad, la contemplación y el cultivo de las virtudes. Esta renuncia era avalada por numerosas referencias bíblicas, entre las cuales destaca una cita literal del Evangelio de Lucas $^{59}$ que Ildefonso introducía en el capítulo 16: "Si alguien quiere venir tras de mí, niéguese a sí mismo" ${ }^{60}$ Ciertamente, esta noción de renuncia había estado ya presente en Isidoro de Sevilla (entre otros), quien, además, había implementado el mismo pasaje en Sentencias. ${ }^{61}$ Sin embargo, mientras el obispo de Hispalis limitaba esta renuncia absoluta a aquellos que decidían dedicarse de lleno a la contemplación de las verdades celestes, el primado de Toledo parecía ampliar su alcance proyectando el modelo de los santos a la totalidad de los bautizados para su consideración e imitación.

quo, cum arbitrii manus extenderimus cogitationumque fuerit palato gustatum, in antiquam perniciem retrahat ad aeternam munditiem iam renatos.

52 Cf. Ildef. De itin. des. 18.

53 Ildef. De itin. des. 72: O beatum desertum, in quo non pedibus corporis, sed cordis motibus itur; in quo non rei ambitio, sed consideratio quaeritur; ubi gradiens animus non lassatur, quia nec crurum poplite iter expletur; ubi non desideratur quando refectio mutetur, sed quando refectionis perfectio inueniatur.

54 Gál 5,22-26.

55 Acerca del uso de las metáforas e imágenes alimenticias, véase Vircillo Franklin 2005. En sus palabras: "Not only prayerful meditation of the word of God, but also communicating it to others by teaching and preaching was commonly described with food metaphors. Augustine recognized a fundamental similarity between learning and eating (...) And he advised teachers to prepare their teaching as if it were food, and to season it appropriately" $(2005,734)$.

56 Este vocabulario es particularmente recurrente en el capítulo 23.

57 Gál 5,19-21.

58 Ildef. De itin. des. 22: Extinguendorum iam spiritalium morborum uirus, quod nullo uoluptatum madente humore in hoc deserto uel oboriri poterit uel fluere, bene singulis speciebus quodammodo insipienti aegroto, cuius aegritudo quare ignota inde deterior, sapiens ille apostolicus sermo describit: Manifesta sunt opera carnis, quae sunt fornicatio, inmunditia, luxuria, idolorum seruitus, ueneficia, inimicitiae, contentiones, aemulationes, irae, rixae, dissensiones, haereses, inuidiae, homicidia, ebrietates, commessationes, et his similia, quae praedico uobis, sicut et praedixi, quoniam qui talia agunt regnum Dei non consequentur.

59 Lc 9,23.

$60 \quad$ Ildef. De itin. des. 16: Si quis uult post me uenire, abneget semetipsum sibi, et tollat crucem suam et sequatur me.

${ }_{61}$ Isid. Sent. 3.18.2: Ad perfectum non sufficit nisi, abnegatis omnibus suis, etiam seipsum quisque abneget; sed quid est seipsum abnegare, nisi uoluptatibus propriis renuntiare? ut qui superbus erat sit humilis, qui iracundus est esse studeat mansuetus. Nam si ita quisque renuntiet quibus possidet omnibus, ut suis non renuntiet moribus, non est Christi discipulus. Qui enim renuntiat rebus suis, sua abnegat; qui uero renuntiat moribus prauis, semetipsum scilicet abnegat. Vnde et Dominus: Qui uult, inquit, post me uenire, abneget semetipsum. 
Ahora bien, si Ildefonso exhortaba explícitamente a adoptar el comportamiento de los santos en el desierto, ¿a quiénes buscaba interpelar concretamente con su mensaje? ¿Cuál era el beatus populus que debía seguir tales pasos por el desierto? ${ }^{62}$ Dada la finalidad pastoral y exégetica, y estableciendo aquí un contrapunto con la postura de Robles, quien había calificado la obra (i.e. De cognitione baptismi y De itinere deserti) de "simple recopilación", ${ }^{63}$ Díaz y Díaz ${ }^{64}$ y Yarza Urquiola, ${ }^{65}$ entre otros especialistas, han coincidido en considerar como principal destinatario del opúsculo al clero visigodo, especialmente a sus más sobresalientes representantes. Asimismo, no se descartaría entre los potenciales destinatarios a un sector de la alta aristocracia, en particular a miembros de la corte real provistos de la educación necesaria para comprender desde la lengua hasta el contenido de la obra. El lector, ya fuese laico o clérigo, debía contar con cierto conocimiento exigido tanto por el tema particular de la obra como por las incorporaciones textuales patrísticas (en su mayor parte de Agustín de Hipona, Gregorio Magno e Isidoro de Sevilla) y bíblicas cuidadosamente ensambladas. El uso sistemático de voces de distinta procedencia, sin embargo, no suponía de forma automática la mera repetición, sino la apropiación simultánea de aquellos enunciados, sustraídos de su contexto de producción (intención, marco genérico, destinatarios), para dotar de sentido nuevas realidades, es decir, nuevos contextos sobre los que arrojaban nueva luz. Asimismo, la inclusión de autoridades bíblicas y patrísticas tampoco era reflejo de la incompetencia o falta de originalidad de quienes elaboraban estos escritos, sino una operación necesaria que al mismo tiempo que transmitía un contenido vital creaba un texto nuevo y creaba también autoridad.

Como ya mencionamos, las instrucciones o pautas impartidas en De itinere deserti apelaban al hombre cristiano, ya bautizado. Por lo tanto, el modelo de conducta que proponía era extendido a todos los fieles, más allá de que los destinatarios reales de la obra se encontraran de hecho solo en un sector reducido del reino. Educar a los más altos estratos de la sociedad había sido ya una iniciativa del obispo de Hispalis, Isidoro, quien en su día había exhortado, principalmente a los reyes, a no ponderar ni enaltecer la trayectoria mundana o la gloria del siglo. En esta misma línea, apelando a un uso simbólico del desierto, Ildefonso enfatizaba aun más aquel mensaje que condenaba vigorosamente "el obstáculo de la pereza", "las aguas de los placeres" y "las interrupciones del ocio". ${ }^{66} \mathrm{Y}$ agregaba: "Todo el que está pegado a lo temporal, no se atreverá, atado como está, a emprender esta felicidad" ${ }^{67}$ Alcanzar este desierto no tenía que ver con el retiro físico a un lugar determinado, sino a prácticas vinculadas con la renuncia, la abstinencia, la austeridad y la rigurosidad. Al reanimar desde Toledo la experiencia del desierto e instar a su audiencia a imitar el modelo de los santos, el toledano reafirmaba determinados criterios y valores que definían el verdadero camino a seguir, un camino que, al elevar nuevamente el distanciamiento de lo

${ }^{62}$ Ildef. De itin. des. 17: O quam beatus populus tale gradiens per desertum, in quo, redemptorem suum habens ducem, hunc solum sequitur, hunc adtendit, tollens crucem uel Domini sui uel suam!

63 Robles 1970, 94: "La lectura detallada de la obra nos revela un simple compilador de textos. Hildefonso copia y recopia, quita, añade y pone lo que le parece bien sobre los textos que le sirven de base. No piensa por cuenta propia; se limita únicamente a decir lo que han dicho los demás. Es más, quiere ser una simple recopilación de la tradición de los antiguos antiquorum monita, como dirá en el Prefacio (...)".

64 Cf. Díaz y Díaz 1970, 55-58.

65 Yarza Urquiola 2007, 282.

66 Ildef. De itin. des. 72.

${ }_{67} \quad$ Ildef. De itin. des. 72: Quicumque temporalibus haeret hanc compeditus nec adgredi pertemptat. 
mundano y material como ideal de perfección, construía una distancia insalvable entre quiénes emprendían esa vía y quiénes no. Se observa, pues, el trasfondo monástico y ascético de la propuesta de Ildefonso, quien, como señalamos, había formado parte del Agaliense, primero como monje y luego como abad de la comunidad. ${ }^{68}$

En este sentido, el toledano (re)creaba valores morales y sociales que trasladaba a la sociedad en la que vivía, escribía y predicaba. Desde la sede episcopal de Toledo, Ildefonso advertía que la salvación efectivamente podía ser alcanzada por todo cristiano, sin distinción de sexo, género, linaje, orden o representación ${ }^{69}$ siempre y cuando las directrices de la moral cristiana fuesen adoptadas correctamente: "En efecto, cuando hay en los pontífices ejemplo de vida sobrenatural y elevación de gloria celestial, en los sacerdotes decorosa gravedad de vida santa y obediencia rendida, en el resto del cuerpo de la Iglesia hay dignidad de costumbres y observancia de los distintos órdenes; en las vírgenes, gloria de castidad; en los continentes, esperanza de premios; en los penitentes el perdón otorgado; en los ricos y en el uso de las riquezas, liberalidad dispuesta a dar, y en los desórdenes, contención de la licencia; en los necesitados ayuda para la vida; en los poderes y en los cargos, humildad verdadera, y en los excesos de piedad, represión de la pesadez; en los cónyuges y prole, honrada libertad; en las pasiones, supresión de la lascivia; este paraje (del desierto) recibe a todos para salvarlos, a todos dirige por este camino para la vida". ${ }^{70}$

Al exhortar a toda la ecclesia a imitar el modelo de los santos, Ildefonso transmitía un conjunto de valores y prácticas, una normativa moral para su comunidad: verdaderos parámetros de conducta que todo integrante de la ecclesia debía contem-

68 Ahora bien, un mensaje centrado en la rigurosidad del desierto no era excepcional en el escenario peninsular de mediados del siglo VII, atravesado por una multiplicidad de experiencias, monásticas y eremíticas, que enarbolaban la austeridad, el ascetismo y el rechazo a los placeres mundanos. Ejemplos de este trasfondo espiritual encontramos en la Regla de Fructuoso o en los escritos de Valerio del Bierzo. Estos, en su mayoría de carácter autobiográfico, dejan entrever aspectos de su itinerario, desde su aislamiento y retiro contemplativo hasta su paso por el monasterio de Rufiana. La búsqueda de la perfección espiritual, por lo tanto, se multiplicaba en derroteros particulares que, en ocasiones, escapaban al control y a la estructura eclesiástica en la medida en que no reconocían intermediario o autoridad, y se arrogaban la iniciativa de explorar un camino espiritual alternativo. Este aspecto es destacado, entre otros, por Díaz 2011, 310-311: "Valerio, educador, taumaturgo y guía espiritual, representa una opción de religiosidad paralela, capaz de dar respuesta a los problemas de personajes procedentes de grupos sociales muy diversos frente a una Iglesia oficial cada vez más institucionalizada y distanciada de los sectores sociales menos favorecidos (...)" Y más adelante: "Valerio puede moverse en los márgenes de la oficialidad, es despreciado por los monjes que llevan una vida regular, denostado por la jerarquía monástica y diocesana, tiene una personalidad alterada que le lleva a sentirse constantemente agredido; sin embargo, en términos comparativos, es un hombre con una gran cultura que pone a disposición de alumnos y discípulos, a la vez que se sitúa en el centro de una sociedad donde su autoridad carismática y la expectativa taumatúrgica que genera provocan una indudable admiración popular". Acerca de Valerio del Bierzo, véase Collins 1986; Martín Iglesias 2006 y 2009; Díaz 2011 y 2013; Martin 2015, entre otros. Un análisis en profundidad sobre la realidad monástica de la península en general, y de la región del noroeste en particular, en Díaz 1990; y sobre el fenómeno del eremitismo en Corullón 1986.

$69 \quad$ Ildef. De itin. des. 72: Non erit de cuiuscumque proposito uel honore, sexu uel ordine, persona uel genere, quem non in peregrinatione mortalitatis huius heremi sanctae istius mansio uel tutandum suscipiens teneat, uel itinere salutari ad mansionem aeternae beatitudinis mittat.

70 Ildef. De itin. des. 72: Nam cum sit in pontificibus exemplum beate uiuendi et celsitudo gloriae caelestis, in sacerdotibus beatae uitae grauitas honesta, in ministris sancta uita oboedientiaque subministrata, in reliquo religionis corpore uenustas morum et ordinum custodia distinctorum; uirginibus incorruptionis gloria, continentibus solatiorum expectatio, paenitentibus indulta remissio, diuitibus et in usu diuitiarum liberalitas prompta, et in inlicitis usibus licentia abscissa, egenis consolatio uitalis, potestatibus et in excellentia honoris humilitas uera et in excessu pietatis adgrauatio cohibenda, coniugibus et in prole honesta libertas et in libitu dempta uoluptas; omnes hic situs ad salutem suscipit, omnes hoc iter ad uitam mittit. 
plar si quería reconocerse en el verdadero camino de salvación. Ahora bien, proponer al desierto como puerto de salvación podía implicar una grave exhortación a los grupos aristocráticos de Toledo, especialmente a los reyes (y potenciales candidatos al trono), cuyas actividades y prerrogativas necesariamente se anclaban en lo mundano y terrenal. Estos debían apartarse de los modos de vida que imponía el siglo, despojarse de todo vicio y encuadrarse dentro del modelo ascético y severo que el obispo proponía como el único verdaderamente cristiano. Por lo tanto, el vínculo indisociable entre ascetismo y cristianismo verdadero que dejaba entrever el toledano en su obra suponía un marco profundamente rigorista y austero, especialmente para los monarcas, quienes, de querer alcanzar una vida más perfecta, debían acercarse a este patrón de conducta que ponderaba la renuncia al mundo por encima de todas las cosas.

Aún más, el desierto se erigía como un auténtico mecanismo de evaluación elaborado desde la más alta jerarquía eclesiástica toledana. En este sentido, era el obispo de la urbs regia, quien instalaba un modo de comportamiento a seguir, requisito indispensable para acceder al descanso eterno. Si bien no es posible conocer el impacto real de este modelo de santidad construido desde Toledo, podemos pensar que un mensaje que hacía del desierto espiritual el único y verdadero camino a la vida futura, pudo haber tensado más de un vínculo entre las distintas sillas episcopales que competían por ocupar un lugar en el podio de la ortodoxia y la santidad, o incluso entre las diversas redes de poder locales que se armaban en torno de aquellas, disputándose su control y administración.

\section{La ciudad regia: ¿un desierto o una nueva Babilonia?}

Cuando Ildefonso accede a las funciones episcopales en el año 657, la sede toledana contaba con un pasado ya consolidado. Desde su establecimiento como simple sede dentro la geografía eclesiástica de la provincia Cartaginense hasta alcanzar la primacía sobre todo el territorio peninsular hacia el fin de la séptima centuria, Toledo transitó un camino de desarrollo y promoción, ${ }^{71}$ inseparable del afianzamiento político de la ciudad y de su crecimiento tanto a nivel económico como cultural. De acuerdo con Velázquez y Ripoll, entre otros especialistas, es a partir del reinado de Leovigildo cuando se produce la fijación de Toledo como única urbs regia, ${ }^{72}$ proceso directamente vinculado con la tendencia unificadora de este rey y con su afán por controlar la totalidad del regnum Gothorum. ${ }^{73}$ En esta línea, su hijo y sucesor Recaredo había afirmado a Toledo como emblema de la nueva fe y ciudad defensora de la ortodoxia al anunciar en el concilio III de Toledo su conversión y la de todo el pueblo

71 Véase, entre otros, Ripoll - Velázquez 2000 y Martin 2003.

72 Las causas que acompañaron la elección de Toledo como asentamiento permanente de la corte regia fueron múltiples y variadas: la posición estratégica, en particular defensiva, de la Meseta Central, la existencia de núcleos poblacionales godos, la importancia histórica y eclesiástica, esta última en crecimiento desde época de Teudis, y la ausencia de hostilidades internas y externas (Cf. Ripoll - Velázquez 2000). Acerca de la elección de Toledo, véase especialmente Martin 2003, 211-216. Entre los factores, la autora destaca la posición interior de la ciudad, su ubicación central en el marco peninsular (cercana a diferentes vías de comunicación) y estratégicodefensiva, y el carácter poco urbanizado de la región. Acerca de la ocupación de la región, véase especialmente los estudios en torno de los yacimientos de la Vega Baja de Toledo (Gallego García 2009; Peña Cervantes García-Entero - Gómez Rojo 2009).

73 Ripoll - Velázquez 2000, 523. 
godo al cristianismo niceno. Con Recaredo, incluso, la ciudad se afianzó como centro político, administrativo y eclesiástico, acompañado por un proceso de renovación edilicia, tanto civil como eclesiástica y monástica. La construcción de la iglesia de los Santos Apóstoles y la basílica de Santa Leocadia, apud urbem regiam, constituyen ejemplos de este desarrollo. ${ }^{74}$ Esta última, de hecho, equiparaba a Toledo con ciudades de larga tradición martirial, específicamente con Mérida, ciudad custodiada por la Santa Eulalia. ${ }^{75}$ Como destacó Díaz y Díaz, la expansión y promoción del culto a Leocadia, la construcción litúrgica de su condición como mártir o confessor, no puede pensarse ajena al papel dominante que ocuparía Toledo dentro del contexto peninsular. En palabras del autor: "precisamente dentro de la política de consolidación de una verdadera capital del nuevo reino, debió surgir la necesidad de promover un culto solemne a la patrona de la ciudad". ${ }^{76}$

Del mismo modo, la devoción mariana recibió nuevos impulsos desde la capital goda. Fue precisamente Ildefonso el responsable de elaborar un tratado en defensa de la maternidad virginal de María, De virginitate sanctae Mariae. ${ }^{77}$ Con esta obra, el toledano situaba a la urbs regia a la par de Oriente y Roma, principales emblemas del culto mariano, el cual había conocido un significativo crecimiento en el periodo posterior a los concilios de Éfeso (431) y Calcedonia (451). Aún más, desde la segunda mitad del siglo IV la devoción a la Virgen se instala entre los Padres de la Iglesia y es desarrollada, por ejemplo, en las obras de Ambrosio de Milán, Jerónimo y los Padres capadocios, Gregorio de Nisa y Gregorio Nacianceno. Asimismo, la documentación escrita y los registros arqueológicos e iconográficos de la época evidencian la proliferación de iglesias, sitios de culto y fiestas consagradas a

74 “...from Leovigild onwards the Visigothic monarchs developed a building policy in the city of Toledo in order to raise its status and prestige, turning it into a real urbs regia, the seat of the kingdom, which included an important set of palace outbuildings (praetorium), with a court chapel dedicated to the Apostles Peter and Paul -with a clear Constantinopolitan resonance- as well as a major basilica dedicated to the Virgin Mary" (Díaz Valverde 2000, 72). La impronta regia en la construcción, especialmente de iglesias, en Toledo se observa también en el caso de Sisebuto y la fundación de la basílica dedicada a la Santa Leocadia, inaugurada en 618 (Martin 2003, 221-225).

75 "[La] reconstrucción o remodelación, quizá incluso un edificio de nueva planta, pero sobre alguno ya existente o sustituyéndolo (...) completaría el prestigio y empaque que daba a la ya tan importante ciudad el tener una mártir propia, cuyas reliquias eran veneradas, al igual que ocurría en Mérida con Santa Eulalia" (Ripoll - Velázquez 2000, 557).

76 Díaz y Díaz 1990, 53.

77 Se han esbozado distintas posturas acerca de la finalidad de De virginitate. Sabemos, en primer lugar, que el obispo de Barcelona, Quirico, recibió aquella obra y escribió al toledano agradeciendo la clara exposición de los misterios contenidos en las Escrituras. Desde esta perspectiva, pues, el opúsculo parecería encerrar una finalidad catequética y pastoral. Asimismo, una modificación en el calendario litúrgico, el desplazamiento de la celebración de la Anunciación a María del mes de marzo al 18 de diciembre, habría ofrecido, además, el contexto propicio para reanimar la devoción mariana en la Península. El traspaso de la conmemoración se establece en el primer canon del concilio X de Toledo celebrado en 656, un año antes de que Ildefonso fuera llamado a ocupar el cargo de metropolitano. De acuerdo con las actas, el motivo principal de esta decisión habría sido que "en muchas partes de España la fiesta de esta santa virgen no se guarda en un mismo día todos los años, porque habiendo pasado los hombres por diversos cálculos del tiempo, es sabido que siguiendo la variedad no conservan la unidad para la celebración". Mediante esta decisión, además, la iglesia de Hispania se distanciaba de la práctica romana que acostumbraba celebrar la fiesta mariana el 25 de marzo. A este escenario Yarza Urquiola (2007) ha de sumar otro factor decisivo en la elaboración del tratado: la presencia judía en la Península, en particular, en el seno de la capital goda. Desde su perspectiva, el componente judío no debe ser soslayado, pues, a pesar del tono impersonal de la obra y del uso de tópicos clásicos de la literatura adversus Iudaeos, reconoce en Ildefonso un auténtico interés, tanto religioso como político, en la elaboración de un tratado en el que el judío adquiere pleno protagonismo. Un relevamiento de las distintas posiciones encontramos en el estudio preliminar que acompaña a la edición más reciente del tratado a cargo de Yarza Urquiola. 
su devoción. ${ }^{78}$ A partir de las primeras décadas del siglo VII, en Bizancio, el culto a María se intensifica, especialmente en Constantinopla, asociada directamente a la Theotokos. ${ }^{79}$

En este marco, Ildefonso retomaba y actualizaba la tradición estableciendo un nexo indisoluble entre la santa virgen y Toledo. ${ }^{80}$ Recordemos, una vez más, que Ildefonso escribía desde la capital y centro neurálgico del reino, el cual -desde 589- se había convertido en núcleo del catolicismo niceno, al ser el sitio elegido por Recaredo para dar a conocer en el contexto del concilio III de Toledo la conversión del pueblo godo y el abandono definitivo de la creencia arriana. De este modo, entonces, también Toledo era elevado como centro protector de la ortodoxia y locus de celebración del culto mariano. La presencia de una catedral en honor a María era desde luego un indicio importante de esa conexión. Empero, a través de la elaboración de un tratado como De virginitate Ildefonso no solo actualizaba un lazo construido desde antiguo, sino que - podemos pensar- creaba un vínculo incluso más especial entre la Virgen y la ciudad.

Una verdadera urbs regia tampoco podía carecer de patronos celestes, protectores espirituales de la ciudad, y del reino entero. Además del registro arquitectónico, el establecimiento de bibliotecas y monasterios, ${ }^{81}$ así como también de una escuela en la corte regia, fueron elementos que contribuyeron a hacer de la capital política una referencia cultural de máxima importancia. Desde luego, Toledo tenía modelos para imitar: Roma y su heredera Constantinopla habían sentado precedentes fundamentales en este sentido.

Ahora bien, con la elevación de Ildefonso a la mitra toledana, tras el pontificado de Eugenio II (646-657), la sede de Toledo retomaba la línea de obispos procedentes de Agali, ${ }^{82}$ como habían sido en el pasado los otrora discípulos del abad Eladio, Justo (633-636) y Eugenio I (636-646). ${ }^{83}$ Poco sabemos de los orígenes de aquel estableci-

78 Acerca del origen y desarrollo del culto mariano, véase Maunder 2008 y los estudios reunidos por Iogna-Prat - Palazzo - Russo 1996. Especialmente para el caso de Bizancio es fundamental el volumen editado por Brubaker - Cunnigham 2011.

79 "Le traumatisme de 626 permit donc d'enregistrer officiellement les progrès du culte marial. Le sanctuaire des Blachernes confirme alors son rôle prépondérant et le type iconographique qui lui est propre: celui de la Vierge Blachernitissa portant l'enfant en médaillon sur la poitrine, étendant les bras en orante et déployant comme une égide le maphorion protecteur. (...) Constantinople, originairement dédiée au Christ, devient alors la ville de la Théotokos" (Dagron 1993, 22).

80 En este vínculo es de fundamental importancia la difusión del tratado de Ildefonso a través de la liturgia. Como destacó Beltrán Torreira 1990, 445: "La obra, dividida en missae, se dio así a conocer integrada en los oficios en honor de Nuestra Señora, lo que presupone como mínimo una fuerte vinculación con los medios eclesiásticos -Toledo en concreto- empeñados en imponer la nueva fiesta".

81 Cf. Caballero Zoreda 1980.

82 La procedencia monástica de los obispos no era un fenómeno extraño en la época. Siguiendo a Sterk, esta práctica se había extendido particularmente en el contexto cristiano del este, a partir de Basilio de Cesarea y más específicamente de Gregorio de Nisa y Gregorio Nacianceno. En palabras de Sterk: "While some earlier bishops had regarded the ascetic movement with suspicion or disdain and monks had spurned or fled ecclesiastical office (...) the Nyssan and the Nazianzen managed to harmonize monastic ideals and practices with active service to the church" (Sterk 1998, 228). El modelo de obispo elaborado por Gregorio de Nisa -continúa Sterk- más que descansar en la nobleza del nacimiento o del honor mundano, se basaba en dos ideales monásticos: el desprendimiento y el amor a Dios. Para el caso de Hispania, sostiene Díaz y Díaz 1970, 47: "Será este cenobio [el Agaliense] el que durante un siglo va a retener, casi en exclusiva, el privilegio de proporcionar obispos a Toledo; el proceso no parece singular, porque algo semejante ocurre entre el monasterio de Cauliana y la metrópoli de Mérida, y el monasterio de Dumio y la sede de Braga".

83 Diversos especialistas destacaron la significativa e imbricada relación entre Agali y Toledo. Entre ellos, García Moreno se refirió a un "auténtico lobby Agaliense en el seno de la Iglesia toledana", haciendo alusión a los 
miento monástico. Las hipótesis al respecto han sido diversas: mientras que algunos autores asignaron su fundación al rey Atanagildo, otros se inclinaron por un origen oriental debido a los nombres de sus santos titulares, Cosme y Damián. ${ }^{84}$ Dejando a un lado el debate acerca de los orígenes, lo cierto es que la impronta de Agali se hizo sentir en Toledo a través de los miembros que habiéndose formado en aquel centro monástico fueron llamados a ocupar la sede episcopal de la capital del reino. Recordemos que Ildefonso había sido convocado al palacio episcopal por Recesvinto, quien se había erigido como monarca único del reino de Toledo en 653 , tras haber sido asociado al trono por su padre (Chindasvinto) durante el periodo 649-653. Recordemos también que Recesvinto había concretado la publicación del código legal conocido como Liber Iudiciorum ${ }^{85}$ (654), instrumento fundamental de consolidación del poder monárquico durante la segunda mitad del siglo VII. Con esta incursión legislativa, el monarca apuntalaba su poder y legitimidad, al ajustarse al modelo de rey sabio y justo y elaborar un código de leyes que no solo daba marcha atrás respecto de ciertas medidas tomadas durante el reinado de su padre, sino que también se apropiaba de la iniciativa legislativa impulsada otrora por aquel. Asimismo, la estrategia desplegada por Recesvinto descansaría en otro significativo elemento: la interrupción de la actividad conciliar. ${ }^{86}$ En este punto, aun si las razones de este prolongado paréntesis en la historia de los concilios visigodos permanezcan todavía inciertas, resulta al menos llamativo que Recesvinto, habiendo ya convocado asambleas conciliares durante su reinado, no haya impulsado la reunión de concilio general alguno desde el año 656 hasta su muerte en 672. Este hecho no pasó desapercibido en los círculos políticos y eclesiásticos toledanos, tal como dejaron entrever las palabras que años más tarde inauguraban el concilio XI de Toledo (675), convocado en el reinado de Wamba, sucesor de Recesvinto y responsable de la reiniciación del ciclo: "Estábamos, pues,

numerosos obispos que, formados en aquel monasterio, se hicieron con el control de la mitra más importante del reino. Cf. García Moreno 1999, 50. Véase también: Rivera Recio 1948, 259-268; García Moreno 1993, 191.

84 Cabe aclarar que, aun aceptada por gran parte de los especialistas, tampoco es conclusiva la identificación de la iglesia de Cosme y Damián con el monasterio Agaliense. Por ejemplo, Gonzálvez Ruiz consideró improbable tanto la fundación de un monasterio católico en manos de un rey arriano, como la presencia de monjes orientales en la Península durante el siglo VI (Cf. Gonzálvez Ruiz 2007, 100). Para este autor, en cambio, “es muy verosímil suponer que el Agaliense fuera también la consecuencia del fervor religioso de alguna persona poseedora de una buena heredad agrícola. De esta manera se habría puesto en marcha la nueva institución monástica, al igual que sucedió en la mayoría de los monasterios de que tenemos información, por decisión de unos señores cristianos ricos y devotos, que dedicaron una finca de los alrededores de Toledo a la fundación de una "iglesia propia", transformando para ello en monasterio una antigua villa romana" (Gonzálvez Ruiz 2007, 101-2).

85 Este corpus legislativo - completado y promulgado por Recesvinto, mas iniciado por su padre Chindasvintocontenía un conjunto diverso de leyes: aquellas denominadas antiquae, que remitían al Código de Eurico o al Codex Revisus de Leovigildo (568-586), otras elaboradas por Recaredo y Sisebuto, y finalmente las redactadas por Chindasvinto y Recesvinto. Según Martin (2008) la promulgación de este código legal en el año 654 significó una verdadera reforma del funcionamiento de la justicia, tanto a nivel institucional como procedimental. Asimismo, destaca la autora, la publicación formal del Liber Iudiciorum había obedecido a intereses concretos de la dinámica política visigoda, vinculados con la construcción de un consenso en torno a Recesvinto, asociado a la imagen del rey justo y bueno en oposición a la figura negativa encarnada por su padre, en un contexto en el cual los lazos familiares o la vía de acceso al trono a través de la asociación no constituían criterios de legitimidad suficientes.

86 La ausencia de concilios de carácter general suscitó explicaciones diversas por parte de los especialistas. Algunas hipótesis adjudican el paréntesis conciliar a la enemistad o tensión entre Recesvinto e Ildefonso, el metropolitano de Toledo a partir de 657; otras, en cambio, lo atribuyen al desgano eclesiástico o bien a la falta de acontecimientos públicos de importancia (por ejemplo, Orlandis 1987, 165). Recordemos en este punto que las únicas reuniones conciliares de este periodo tuvieron carácter provincial, como el concilio de Mérida en 666. En 681 el rey Ervigio convocaría a un nuevo concilio general, el XII de Toledo. 
hasta ahora poco seguros a causa de los trastornos de estos tiempos, porque el paso de los años, apagada la luz de los concilios, no había aumentado tan sólo los vicios, sino que introducía en las mentes sin cultivo la ignorancia madre de todos los errores. Veíamos, pues, como la caldera encendida de la confusión Babilónica alejaba la época de los concilios y complicaba a los obispos del señor en costumbres disolutas; pues se inclinaban a las invitaciones de la meretriz vestida de púrpura porque no existía ya la disciplina conciliar, ni había quien pudiera corregir a los que erraban, puesto que estaba desterrada la palabra divina, y como no se mandaba que se reuniesen los obispos, la vida corrompida aumentaba cada día", 87

Pero el rey no estaba solo en Toledo. El metropolitano, Ildefonso, formularía en sus obras otro tipo de modelo o conducta ejemplar: como vimos, se trataba de un ideal de santidad, rigorista y ascético, al que asignaba contornos bien definidos, y aun más difíciles de ser asumidos por un monarca, vinculados con la renuncia y la austeridad. Al enarbolar estos pilares, más próximos a la vida contemplativa que a una vida estrictamente secular, Ildefonso desplegaba una guía para su comunidad, especialmente dirigida a los conductores de la grey.

El desierto intervenía en este contexto, irrumpía con su impronta ascética para definir lo que en última instancia era considerado por la jerarquía eclesiástica toledana como el máximo índice de santidad. Nada podía equipararse con la autoridad emanada del ejemplo de los santos y su riguroso ascetismo. Ni siquiera el rey ni sus leyes terrenales. De esta forma, la mirada episcopal apostaba a otros índices que en vez de enfatizar la presencia o prerrogativa del monarca, ponían el acento en la conducta de los santos. En este sentido, el desierto, nuevamente activo gracias al toledano, actuaba sobre la configuración de límites al mismo tiempo que consolidaba y creaba autoridad.

Como hemos visto, en De itinere deserti la preocupación por alcanzar la vida futura vislumbraba un fuerte componente moral, visible en las pautas que apuntaban a disciplinar el cuerpo, controlar los vicios y combatir las tentaciones demoníacas. El hombre debía estar preparado para llegar en óptimas condiciones al juicio y poder así formar parte de los elegidos que vivirían eternamente en el reino de los cielos. Ildefonso, por lo tanto, se mostraba convencido de que, al seguir los pasos de los santos en el desierto, renunciando a los placeres carnales y practicando en vida una ascesis rigurosa, el hombre podía alcanzar, gracia divina mediante, la salvación de la eterna beatitud. El toledano se inspiraba una vez más en el corpus paulino para transmitir a los fieles un mensaje de esperanza: “...el desierto entero de la vida presente, desprovisto de los consuelos del mundo, será apreciado por la esperanza del consuelo futuro, porque a la patria de los bienaventurados no se va mejor ni más aprisa que por las angosturas de los sufrimientos, según las palabras de Pablo: ${ }^{88}$ No son los padecimientos de esta vida comparables a la gloria futura que se manifestará en nosotros". ${ }^{89}$

87 Tol. XI: Eramus enim hucusque prolabentis saeculi collunione instabiles, quia annosa series temporum subtracta luce conciliorum non tam uitia auxerat quam matrem omnium errorum ignorantiam otiosis mentibus ingerebat. Cernebamus enim quomodo Babilonicae confusionis olla succensa nunc tempora conciliorum auerteret, nunc sacerdotes Domini de resolutis moribus irretiret. Purpuratae enim meretricis sequebantur inuitamenta, quia ecclesiastici conuentus non aderat disciplina nec erat qui errantium corrigeret partes cum sermo diuinus haberetur extorris. Et quia non erat adunandorum pontificum ulla praeceptio, crescebat in maius uita deterior (...).

88 Rom 8,18.

89 Ildef. De itin. des. 18: Sic tota heremus uitae praesentis mundi destituta solatiis, spe futurae consolationis amabitur, quoniam ad patriam beatorum non melius, non celerius itur quam per angustias passionum, dicente Paulo: non sunt condignae passiones huius temporis ad futuram gloriam, quae reuelabitur in nobis. 
Con estas palabras, y autoridad paulina mediante, Ildefonso insistía, pues, en las leyes divinas que regían la nueva sociedad a la cual el hombre ingresaba después del bautismo e indicaban cuál era el verdadero camino de salvación. Estas leyes, y no las de los hombres, estaban en el centro de la reflexión toledana y se erigían como principales orientadoras en el itinerario hacia la mansión celeste. Del mismo modo, el toledano recogía nuevamente las palabras de Pablo en su Carta a los Gálatas ${ }^{90}$ para señalar y afirmar vehementemente que aquellos que sucumban ante los placeres de la carne "no heredarán el reino de los cielos". ${ }^{91}$ Una vez más, la rectitud moral aparecía como requisito y condición necesaria para esperar la recompensa en el futuro y eterno reino de los cielos.

\section{Consideraciones finales}

Hemos visto que la actualización del episodio bíblico del Exodo, la marcha del pueblo de Israel en el desierto, constituía un símbolo del itinerario o trayecto espiritual del hombre bautizado en un mundo de carácter transitorio. Representaba, de hecho, el camino que conducía al descanso eterno de la vida futura, un destino que se alcanzaba una vez superados los obstáculos y las tentaciones que acechaban constantemente al hombre. De esta manera, el De itinere deserti de Ildefonso no se ceñía al sentido literal del acontecimiento veterotestmentario, sino que enseñaba su sentido oculto y verdadero, el de la marcha espiritual, y a partir de este proyectaba un ideal de comportamiento basado en prácticas ascéticas y en la renuncia radical a los placeres terrenales y bienes materiales. Si bien tales pautas difícilmente podían ser llevadas a cabo por la totalidad de la ecclesia, establecían unos criterios de santidad que ejercían un significativo contraste con el siglo y los valores mundanos. No podemos dejar de destacar la impronta episcopal que -apelando al sustrato bíblico y patrístico- construía patrones de conducta, modelaba las prácticas y articulaba mecanismos de control y evaluación pertinentes para ordenar y preparar al pueblo en su conjunto, pero especialmente a la más alta jerarquía, para asumir el papel asignado en el reino eterno de Dios. La interpretación espiritual de la letra bíblica se tornaba, de este modo, fundamental para la vida presente, es decir, intervenía en el día a día ofreciendo, por un lado, valiosas enseñanzas acerca de cómo entender los escritos del Antiguo Testamento y, por otro, valores y formas de comportamiento a imitar.

En este camino, además, el hombre no se encontraba sin protección. Como indicaba Ildefonso, el viajero era agraciado con dones espirituales otorgados por el Espíritu Santo que lo orientaban hacia la vida futura. Se advertía, de este modo, la centralidad que Ildefonso otorgaba al elemento carismático en la construcción del vínculo entre el hombre y la divinidad. El toledano recordaba a sus lectores la activa intervención divina en la tierra independientemente del rango, posición o riqueza, pues el verdadero cristiano no se enaltecía por la posesión de bienes materiales o por los hábitos mundanos, sino que buscaba refugio en la humildad, el cultivo de las virtudes y la devoción.

Asimismo, este mensaje centrado en el desierto emanaba de Toledo, capital del reino visigodo, y específicamente de su sede episcopal. Escribir desde este empla-

Gál 5,19-21.

91 Ildef. De itin. des. 22. 
zamiento implicaba que, en primer lugar, desierto y ciudad no solo no eran opuestos irreconciliables, sino que la ciudad en general, y Toledo en particular, podía funcionar como un desierto espiritual. Tampoco las funciones episcopales eran ajenas al universo del desierto que Ildefonso proponía evocar. En definitiva, llevar el modelo de comportamiento al límite de la rigurosidad era un modo también de disciplinar al propio cuerpo de clérigos que debía encarar día tras día la preparación de las respectivas comunidades de fieles. En segundo lugar, diseñar una estrategia de autoridad basada en el desierto implicaba un severo obstáculo y una vara demasiado elevada para aquellos que dedicados de lleno a los asuntos de este mundo no lograban llevar una vida conforme a los preceptos ascéticos. Aun sin poder conocer a ciencia cierta qué esperaba Ildefonso con la difusión de un mensaje de estas características (recordemos, una vez más, que la adopción de una vida contemplativa era propia de unos pocos), la sola enunciación del desierto transmitía una santidad y una rectitud moral difíciles de igualar. Con este mensaje el metropolitano (quien, además, contaba con un pasado monástico en el Agaliense) impartía una sabiduría necesaria para conducir a los fieles a su destino final, una sabiduría que en definitiva incomodaba con su rigurosidad y severo ascetismo, advirtiendo a todo aquel que buscaba encaminarse hacia el verdadero destino, ese que esperaba a los elegidos en el reino eterno de Dios.

Para concluir, resulta conveniente retomar los primeros capítulos de De itinere deserti. Allí, el toledano se había encargado de enmarcar al desierto dentro de un esquema mayor comprendido por tres periodos sucesivos que ilustraban en términos generales el devenir del hombre. Decía Ildefonso: "Primero, cuando [el hombre] después de ser creado feliz cayó engañado. Segundo, cuando fue restaurado por la muerte del Mediador. Tercero, cuando, gracias al don de la redención, será perpetuamente glorioso". ${ }^{22}$ En este plan, el desierto ocupaba un lugar central, puesto que en tanto símbolo de la vida presente planteaba cuál debía ser la conducta necesaria a los efectos de alcanzar el descanso eterno. El desierto, pues, era situado dentro de un marco establecido y definido por la tradición y las Escrituras, al mismo tiempo que reclamaba unos ideales ascéticos que instaba a que fuesen practicados dentro de la Iglesia. En definitiva, el tránsito del hombre a través del desierto estaba encaminado al tercer y último periodo, es decir, a la llegada del reino de los cielos, donde los elegidos esperaban permanecer con Cristo eternamente.

\section{Referencias bibliográficas}

Beltrán Torreira, F. (1990): "San Ildefonso de Toledo y el culto a la virgen en la Iglesia Hispano-visigoda: problemas históricos y doctrinales", [en] AA.VV., Devoción mariana y sociedad medieval: actas del simposio, Ciudad Real, 439-454.

Braegelmann, A. (1942): The Life and Writings of Saint Ildefonsus of Toledo. A Dissertation... (=The Catholic University of America. Studies in Mediaeval History VI), Washington.

Brubaker, L. - Cunnigham, M. (eds.), (2011): The Cult of the Mother of God in Byzantium: Texts and Images (=Birmingham Byzantine and Ottoman Studies 11), Farnham.

Burton-Christie, D. (1993): The Word in the Desert: Scripture and the Quest for Holiness in Early Christian Monasticism, Oxford.

92 Ildef. De itin. des. 1. 
Caballero Zoreda, L. - Latorre Macarrón, J. I. (1980): La iglesia y el monasterio visigodo de Santa María de Melque (Toledo). Arqueología y arquitectura. San Pedro de la Mata (Toledo) y Santa Comba de Bande (Orense), (=Excavaciones Arqueológicas en España 109), Madrid.

Campos Ruiz, J. (1971): “El camino del desierto", [en] V. Blanco García - J. Campos (eds. \& trads.), Santos Padres Españoles I. San Ildefonso de Toledo, Madrid.

Castellanos, S. (1998): Poder social, aristocracias y hombre santo en la Hispania visigoda. La Vita Aemiliani de Braulio de Zaragoza (=Biblioteca de Investigación 20), Logroño.

Cazier, P. (ed.), (1998): Isidorus Hispalensis Sententiae (=CCSL 111), Turnhout.

Collins, R. (1986): “The 'autobiographical' Works of Valerius of Bierzo: Their Structure and Purpose", Antigüedad y Cristianismo 3, 425-442.

Corullón, I. (1986): “El eremitismo en las épocas visigoda y altomedieval a través de las fuentes leonesas I", Tierras de León. Revista de la Diputación Provincial 26/63, 47-62.

Dagron, G. (1993): “L’Église et la chrétienté byzantines entre les invasions et l'iconoclasme (VII ${ }^{\mathrm{e}}$-début VIII ${ }^{\mathrm{e}}$ siècle)", [en] G. Dagron - P. Riché - A. Vauchez, Histoire du christianisme, tome IV: évêques, moines et empereurs (610-1054), Paris, 9-91.

Díaz, P. C.

(1986): "Comunidades monásticas y comunidades campesinas en la España visigoda", Antigüedad y Cristianismo 3, 189-195.

(1990): "El monacato y la cristianización del NO hispano. Un proceso de aculturación", Antigüedad y Cristianismo 7, 531-539.

(1999): "Monasticism and liturgy in Visigothic Spain", [en] A. Ferreiro (ed.), The Visigoths. Studies in Culture and Society (=The Medieval Mediterranean 20), Leiden, 169200.

(2011): "El eremitismo en la Hispania visigoda: Valerio del Bierzo y su entorno", [en] J. A. García de Cortázar - R. Teja (eds.), El monacato espontáneo: eremitas y eremitorios en el mundo medieval, Aguilar de Campoo, 57-84.

(2013): "Valerio del Bierzo: la equívoca marginalidad de un asceta tardoantiguo", [en] R. González Salinero (ed.), Marginados sociales y religiosos en la Hispania tardorromana y visigoda (=Thema Mundi 5), Madrid-Salamanca, 293-315.

Díaz, P. C. - Valverde, M. R. (2000): "The Theoretical Strength and Practical Weakness of the Visigothic Monarchy of Toledo", [en] F. Theuws - J. Nelson (eds.), Rituals of Power (=Transformation of the Roman World 8), Leiden, 59-93.

Díaz y Díaz, M. C.

(1970): "La obra literaria de los obispos visigóticos toledanos: supuestos y circunstancias", [en] La Patrología toledano-visigoda, Madrid, 45-63.

(1990): "Cuestiones en torno al culto de Santa Leocadia", [en] J. Connolly - A. Deyermond - B. Dutton (eds.), Saints and their Authors: Studies in Medieval Hispanic Hagiography in Honor of John K. Walsh, Madison, 47-54.

Dijkstra, J. - van Dijk, M. (eds.), (2006): The Encroaching Desert. Egyptian Hagiography and the Medieval West, Leiden.

Dunn, M. (2000): The Emergence of Monasticism: From the Desert Fathers to the Early Middle Ages, Oxford (https://doi.org/10.1002/9780470754580).

Fernández Ardanaz, S. (1999): "Monaquismo oriental en la Hispania de los siglos VI-X", Antigüedad y Cristianismo 16, 203-214.

Fredriksen, P. - Irshai, O. (2006): “Christian Anti-Judaism: Polemics and Policies”, [en] S. Katz (ed.), The Cambridge History of Judaism, vol. IV, Cambridge, 977-1034 (https://doi. org/10.1017/CHOL9780521772488.040). 
Gallego García, Ma del M. (ed.), (2009): La Vega Baja de Toledo, Toledo.

García Moreno, L.

(1993): "Los monjes y monasterios en las ciudades de las Españas tardorromanas y visigodas", Habis 24, 179-192.

(1999): "Disenso religioso y hegemonía política", 'Ilu. Revista de Ciencias de las Religiones 2, 47-63.

Goehring, J. (1999): Ascetics, Society and the Desert: Studies in Early Egyptian Monasticism, Harrisburg.

Gonzálvez Ruiz, R. (2007): “Agali. Historia del monasterio de san Ildefonso”, Toletum 2/54, 99-145.

Guillaumont, A. (1975): "La conception du désert chez les moines d'Egypte", Revue de l'histoire des religions 188/1, 3-21 (http://dx.doi.org/10.3406/rhr.1975.6077).

Iogna-Prat, D. - Palazzo, E. - Russo, D. (eds.), (1996): Marie. Le culte de la vierge dans la société médiévale, Paris.

Kannengiesser, C. (2004): Handbook of Patristic Exegesis (=The Bible in Ancient Christianity 1), Leiden, 2 vols.

Leyser, C. (2000): Authority and Ascetism from Augustine to Gregory the Great, Oxford (http://dx.doi.org/10.1093/acprof:oso/9780198208686.001.0001).

Madoz, J. (1952): “San Ildefonso de Toledo", Estudios eclesiásticos 26, 467-505.

Martin, C.

(2003): La géographie du pouvoir dans l'Espagne visigothique, Lille.

(2008): “La réforme visigothique de la justice: les années Recceswinth", [en] N. Guglielmi - A. Rucquoi (eds.), Derecho y justicia: el poder en la Europa medieval. Droit et justice: le pouvoir dans l'Europe medievale, Buenos Aires, 37-57.

(2015): "Valerius et l'ennemi. Grands proprietaires, clercs, cénobites et ermites face au contrôle du sacre dans le Bierzo du VII siècle", [en] Ph. Depreux et alii (éds.), Compétition et sacré au haut moyen âge: entre médiation et exclusion (=Haut Moyen Âge 21), Turnhout, 67-84.

Martín Iglesias, J.

(2006): “¿Valerio en Compludo? Examen crítico de los Opúsculos autobiográficos (CPL 1282-1284) y las Visiones del más allá (CPL 1277-1279) de Valerio del Bierzo", Veleia 23, 327-338.

(2009): "La biografía dentro de la autobiografía: el caso de Valerio del Bierzo (siglo VII)", [en] V. Valcárcel Martínez (ed.), Las biografías griega y latina como género literario. De la Antigüedad al Renacimiento. Algunas calas (=Anejos de Veleia. Series Minor 26), Vitoria-Gasteiz, 319-342.

Martín Viso, I.

(2011): "Monasterios y redes sociales en el Bierzo altomedieval", Hispania. Revista Española de Historia 71/237, 9-38 (http://dx.doi.org/10.3989/hispania.2011.v71.i237.334). (2012): "The Memory of Holy Men in Hispanic Monasticism", Imago Temporis. Medium Aevum 6, 165-190.

Martínez Díez, G. - Rodríguez, F. (eds.), (2002): La colección canónica hispana. VI. Concilios hispánicos: tercera parte, Madrid.

Maunder, C. (ed.), (2008): The Origins of the Cult of the Virgin Mary, London.

Orlandis, J. (1987): Época visigoda (409-711), Madrid.

Oroz Reta, J. - Marcos Casquero, M. (eds. \& trads.), (2004): San Isidoro de Sevilla. Etimologías, Madrid. 
Peña Cervantes, Y. - García-Entero, V. - Gómez Rojo, J. (2008): “Aportaciones al conocimiento de la evolución histórica de la Vega Baja de Toledo. Estudio preliminar de la excavación de la parcela R-3", Espacio, Tiempo y Forma, Serie I, Nueva época. Prehistoria y Arqueología 2, 157-175 (https://doi.org/10.5944/etfi.2.2009.1955).

Rapp, C. (2005): Holy Bishops in Late Antiquity: The Nature of Christian Leadership in an Age of Transition (=Transformation of the Classical Heritage 37), Berkeley-Los Angeles-London (http://dx.doi.org/10.1525/california/9780520242968.001.0001).

Ripoll, G. - Velázquez, I. (2000): “Toletum, la construcción de una urbs regia”, [en] G. Ripoll - J. M. Gurt Esparraguera (eds.), Sedes regiae (ann. 400-800), (=Memorias de la Real Academia de Buenas Letras de Barcelona 25), Barcelona, 521-578.

Rivera Recio, J. (1948): “Cisma episcopal en la Iglesia Toledanovisigoda?”, Hispania Sacra 1, 259-268.

Robles, L. (1970): “Anotaciones a la obra de San Hildefonso «De cognitione baptismi»", Saitabi 20, 73-146.

Sterk, A.

(1998): "On Basil, Moses, and the Model Bishop: The Cappadocian Legacy of Leadership", Church History 67/2, 227-253 (http://dx.doi.org/10.2307/3169760). (2004): Renouncing the World Yet Leading the Church, Cambridge.

van Uytfanghe, M. (1985): “L'empreinte biblique sur la plus ancienne hagiographie", [en] J. Fontaine - Ch. Pietri (éds.), Le monde latin antique et la Bible, Paris, 565-611.

Velázquez Soriano, I. (2007): La literatura hagiográfica: presupuestos básicos y aproximación a sus manifestaciones en la Hispania visigoda (=Libros singulares 17), Burgos.

Vircillo Franklin, C. (2005): "Words as Food: Signifying the Bible in the Early Middle Ages", [en] AA.VV., Comunicare e significare nell'alto medioevo, Spoleto, 733-764.

Vives, J. (ed. \& trad.), (1963): Concilios visigodos e hispanoamericanos, Madrid.

Vogüé, A. de (2007): Histoire littéraire du mouvement monastique dans l'antiquité, Paris.

Yarza Urquiola, V. (ed.), (2007): Ildefonsi Toletani episcopi De uirginitate sanctae Mariae, De cognitione baptismi - De itinere deserti, De uiris illustribus (=CCSL 114A), Turnhout. 